\title{
Kuluttajien näkemykset kotimaisesta omenasta
}

\author{
Merja Mäkinen ${ }^{1)}$ ja Sirkka Malkki ${ }^{2)}$ \\ ${ }^{1)}$ Työtehoseura ry, maatalousosasto, Pl 13,05201 Rajamäki, merja.makinen@sanet.fi \\ ${ }^{2)}$ Työtehoseura ry, maatalousosasto, Pl 13, 05201 Rajamäki, sirkka.malkki@tts.fi
}

\begin{abstract}
Johdanto
Suomalaisen kuluttajan näkemyksiä omenan laadusta, saatavuudesta ja käyttötavoista on selvitetty vain vähän eikä kotitarveviljelyn laajuutta ja merkitystä ole kartoitettu. Myynnin ja menekinedistämisen kannalta on tärkeää tietää kuluttajien mielipiteet tuotteesta ja ostokäyttäytymisestä. Tämän tutkimuksen tarkoituksena oli selvittää minkälaisena kuluttaja koki kotimaisen omenan saatavuuden syksyllä 2003, mitkä tekijät olivat kotimaisen omenan laadun kannalta tärkeitä ja minkälaista omenaa kuluttaja on halukas ostamaan ja käyttämään. Lisäksi kartoitettiin kotitarveviljelyn laajuutta ja sen vaikutusta omenan kysyntään. Tutkimushypoteesina oli, että kotimaisen omenan osto tai käyttö ei riipu kuluttajan näkemyksistä ja mielikuvista omenan laadusta, saatavuudesta ja esillepanosta eikä omenan kotitarveviljelystä. Tutkimus on Helsingin yliopiston Soveltavan biologian laitoksen, puutarhatieteen opinnäytetyö ja samalla osa Työtehoseuran laajempaa tutkimuskokonaisuutta: "Kotimaisen omenan kuluttajalähtöinen markkinointi".
\end{abstract}

\section{Aineisto ja menetelmät}

Tutkimuksen viitekehitys pohjautuu Shepherdin \& Sparksin (1994) malliin. Sen mukaan ruoanvalintaan vaikuttavat tekijät jaetaan seuraavasti: 1) ruokaan itseensä liittyviin, 2) yksilöön liittyviin sekä 3) sosiaalisiin ja taloudellisiin tekijöihin. Yksilölliset, taloudelliset ja sosiaaliset valintatekijät vaikuttavat valintapäätöksiin välillisesti asenteiden kautta. Asenteet, myönteiset tai kielteiset suhtautumisvalmiudet vaikuttavat ihmisen toiminta-aikomukseen. Aikomuksen toteutuminen riippuu yksilön käyttäytymisestä ja käytännön toimintamahdollisuuksista (kuten ruoan saatavuudesta ja hinnasta) sekä resursseista.

Tutkimus toteutettiin survey- eli kyselytutkimuksena. Kyselylomake sisälsi strukturoituja kysymyksiä ja väittämiä, joita oli täydennetty muutamalla avoimella kysymyksellä. Erityisesti haluttiin spontaaneja perusteluita siitä, miksi vastaajat ostavat tai eivät osta kotimaista omenaa sekä sanallisia kommentteja kotimaisen omenan laadusta ja saatavuudesta. Väittämiä mitattiin 4-, 5- ja 7portaisella Likertin asteikolla.

Lomake laadittiin viitekehysmallin mukaisesti kolmesta osa-alueesta: 1.) Kuluttajan käyttäytymistä mitanneista omenan ostosta, ostomotiiveista ja käytöstä, 2.) Kuluttajan suhtautumisesta omenan laatuun, saatavuuteen ja kotimaisuuteen sekä 3.) Omenan kotitarveviljelyn laajuutta ja merkitystä mitanneesta osiosta. Näitä toimintoja haluttiin tarkastella kysymysten loppuun sijoitettujen demograafisten ryhmittelytekijöiden lisäksi suomalaisessa mansikkatutkimuksessa kehitettyä elämäntyyliteoriaa (Tillgrén 2002) vasten. Tällä pyrittiin saamaan tutkimustuloksiin syvyyttä. Demografisilla tekijöillä ei kyetä selittämään, miksi ostajat valitsevat eri vaihtoehdoista juuri tietyn tuotteen (Bergström \& Leppänen 1999). Tämän tyyppisiin kysymyksiin pyritäänkin vastaamaan ns. kuluttajien elämäntyylitekijöillä. Elämäntyyleillä tarkoitetaan yksilön tapaa elää, hänen suhtautumistaan elämään ja ympäristöön sekä sitä, miten hän käyttää aikaansa ja rahaansa (Bergström \& Leppänen 1999). Elämäntyylejä mitattiin ruokaan, ympäristöön ja vapaa-aikaan liittyvillä arvoväittämillä sekä harrastuksia selvittävillä kysymyksillä. Tillgrénin (2002) mansikankuluttajien elämäntyyliteoria pohjautuu mm. Grunertin ym. (1993) elämäntyylitutkimuksiin.

Kysely tehtiin marraskuussa 2003. Kyselylomakkeiden toimivuutta testattiin ennakkoon ja palautteen perusteella tarkistettiin kysymysten toimivuutta. Tutkimuksen perusjoukoksi valittiin Manner-Suomessa asuvat 18-75 -vuotiaat henkilöt. Ositettu otanta perustui omenapuiden menestymisvyöhykejakoon ja toisaalta kaupunki vs. maaseutu mukaiseen jaotteluun.

Valitut paikkakunnat olivat: Helsinki, Hyvinkää, Lohja ja Lappeenranta (I-II-vyöhyke), Kokkolan ja Ylä-Savon seutukunnat (IV-V-vyöhyke) sekä Kemi-Tornion ja Rovaniemen seutukunnat (VI-VII-vyöhyke). Helsinki jaettiin lisäksi eteläiseen, itäiseen ja läntiseen piiriin. Omenan ammattimainen viljely on keskittynyt I-II.vyöhykkeelle. IV-V-vyöhykkeellä sitä ei enää ole, mutta kotitarveviljelyyn alue soveltuu hyvin, kun valitaan kestäviä lajikkeita ja sopiva perusrunko (Krannila \& Paalo 1996). Omenasadon saamiseksi kotipuutarhasta kuudennella vyöhykkeellä, mihin KemiTornion seutukunta sijoittuu, on tehtävä paljon työtä (emt.). 
Postikyselyn osoitteisto poimittiin väestörekisteri-keskuksen väestöjärjestelmästä. Kyselyjä lähetettiin $2045 \mathrm{kpl}$, joista perille menneiden lukumäärä oli $2038 \mathrm{kpl}$. Määräaikaan mennessä vastauksia saatiin $642 \mathrm{kpl}$, minkä jälkeen lähetettiin muistutuskirje. Vastauksia saatiin yhteensä $738 \mathrm{kpl}$. Vastausprosentiksi muodostui näin $37 \%$. Paikkakunnittain vastausprosentti vaihteli $33-40 \%$. Aktiivisimpia vastaamaan olivat hyvinkääläiset ja helsinkiläiset. Vähinten kiinnostusta kysely herätti Rovaniemen ja Kemi-Tornion seutukunnissa sekä Lohjalla.

Survey-tutkimuksen tulokset käsiteltiin kvantitatiivisesti. Kvantitatiivinen tutkimus vastaa kysymyksiin miten moni, miten paljon, miten usein ja miten tärkeä jokin asia on (Lotti 1996). Aineisto analysoitiin käyttäen frekvenssejä sekä ristiintaulukointia.

\section{Tulokset ja tulosten tarkastelu}

Tutkimukseen vastanneista $65 \%$ oli naisia. Vastanneista $73 \%$ asui kaupunkien keskustoissa, esikaupunkialueella tai lähiössä. Maaseudun haja-asutusalueella asuvia tutkimukseen osallistui $16 \%$. Vastanneista $65 \%$ oli alle 55 vuotiaita. Lapsiperheitä oli $31 \%$, lapsettomia avio- tai avopareja $39 \%$ ja yksinasuvia 22\%. Työntekijöitä ja toimihenkilöitä vastanneista oli $50 \%$ ja eläkeläisiä $10 \%$ sekä muutoin työelämän ulkopuolella olevia $27 \%$. Tutkimukseen osallistuneista $85 \%$ vastasi pääosasta tai vähintään puolesta taloutensa ruokaostoksista. Talouden yhteenlaskettujen bruttotulojen jakaumassa yli $2000 €$ kuukaudessa ansaitsevien osuus oli $63 \%$.

Vastanneista enin osa osti omenoita 2-4 kertaa kuukaudessa tai useammin $(\mathrm{n}=730)$ syksyn 2003 aikana. Noin joka kolmas ( $\mathrm{f}=266)$ osti omenat mitaten kg:na ja kaksi kolmesta $(\mathrm{f}=484)$ kappaleittain. Omenan tyypillinen, keskimääräinen kertaostos oli $1,4 \mathrm{~kg}$ tai $5 \mathrm{kpl}$. Omenat ostetaan päivittäistavaramyymälästä $(\mathrm{f}=633)$ ja jonkin verran myös torilta $(\mathrm{f}=205)$. Vastanneista $73 \%$ $(n=729)$ ilmoitti ostaneensa ulkomaisia omenoita 6-12 kertaa viimeksi kuluneen vuoden aikana, kun vastaavasti $38 \%(n=732)$ oli ostanut yhtä usein kotimaisia omenoita. Ulkomaista omenaa ei ostanut lainkaan $6 \%$ ja kotimaista $18 \%$ vastanneista. Ostomotiiviväittämistä: "omenat ovat terveellisiä", "omena on mieluisampi vaihtoehto kuin suklaapatukka", "omenat ovat ravitsevia ilman, että ne sisältäisivät runsaasti energiaa" ja "omena on siistiä syötävää, helppo pitää mukana ja tarjota kaverillekin" täysin tai jokseenkin samaa mieltä oli $\geq 90 \%$ vastanneista. Väite, ettei omenaa tarvitse kuoria, jakoi vastanneet selkeästi ja tasaisesti samaa ja eri mieltä oleviin. Väitteestä, ettei ole merkitystä sillä onko omena kotimainen vai ulkomainen, $58 \%$ oli täysin tai jokseenkin eri mieltä. Vastanneista 70 $\%$ perusteli sanallisesti syitä miksi he ostavat tai eivät osta kotimaista omenaa. Perustelut on jaoteltu saman tyyppisiin luokkiin ja tulokset on esitetty Taulukossa 1.

Taulukko 1. Syyt ostaa $(n=409)$ ja olla ostamatta $(n=464)$ kotimaista omenaa

\begin{tabular}{lrrlrr}
\hline Syy ostaa & \multicolumn{1}{c}{ f } & \multicolumn{1}{c}{$\%$} & Syy olla ostamatta & $\mathrm{f}$ & $\%$ \\
\hline Säilöntä- tai lisäaineeton, puhdas & 110 & 27 & Hinta & 114 & 25 \\
Maku & 82 & 20 & Saatavuus & 95 & 20 \\
Kotimaisuuden suosiminen & 49 & 12 & Saa muilta, kasvattaa itse & 66 & 14 \\
Voi syödä kuorineen & 35 & 9 & Hapan, väkevä, kirpeä & 37 & 8 \\
Lähiruoka, tuttu alkuperä/viljelijä & 27 & 6 & Laatu & 31 & 7 \\
Laatu & 24 & 6 & Pienikokoinen & 31 & 7 \\
Sopiva leivontaan, soseeksi & 16 & 4 & Maku & 21 & 5 \\
Terveellinen & 12 & 3 & Lajike, valikoima & 18 \\
Tuoksu & 10 & 2 & Ulkonäkö, rupisuus & 14 \\
Tuoreus & 9 & 2 & Alkuperä-, lajikemerkinnät & 12 & 3 \\
\hline
\end{tabular}

Vastanneista ( $\mathrm{n}=719)$ lähes puolet ilmoitti syöneensä omenoita syksyn 2003 aikana päivittäin tai lähes päivittäin. Näistä $29 \%(\mathrm{f}=208)$ oli kotimaisia. 13 henkilöä ilmoitti, ettei syö lainkaan omenaa allergian vuoksi tai siksi, ettei yksinkertaisesti pidä siitä. Tämän lisäksi 7 kertoi voivansa syödä kotimaisia omenoita, vaikka ulkomaiset aiheuttavat allergisia reaktioita. Ruoanvalmistuksessa omenaa käytettiin yleisesti vain omenapiirakassa $(\mathrm{f}=424)$ ja jonkin verran jälkiruoissa. Reilu kolmannes (f=348) kertoi säilövänsä omenoita soseena tai hillona. Muut säilöntätavat olivat vähäisiä. Yli puolet vastaajista ilmoittivat säilyttävänsä omenat huoneenlämmössä, pöydällä. 
Omenan laadun kannalta tärkeimpinä ominaisuuksina pidettiin: makua, tuoreutta, sopivaa kypsyyttä, mehukkuutta ja aromia. Edellä mainitut ominaisuudet on lueteltu tärkeysjärjestyksessä. Näiden jälkeen kuudennella sijalla vasta tuli makeus ja sen jälkeen virheettömyys ja rapeus/kiinteys. Ei lainkaan tai ei juurikaan tärkeinä ominaisuuksina koettiin omenan muoto, värittyneisyys ja koko sekä vain vähän tärkeinä ohutkuorisuus ja hapokkuus. Se, että kotimaisen omenan voi syödä kuorineen, ei vastanneiden näkemyksien mukaan liittyisi kotimaisen omenan kuoren ohuuteen vaan olettamukseen, että kotimaiset omenat ovat säilöntä- ja lisäaineettomia.

Vastaajia pyydettiin arvioimaan kotimaisen omenan tarjontaan syksyn 2003 aikana liittyviä väittämiä. Kuviossa 1 on esitetty vastanneiden kokema ominaisuus suhteessa siihen, miten tärkeänä vastanneet pitivät ominaisuutta.

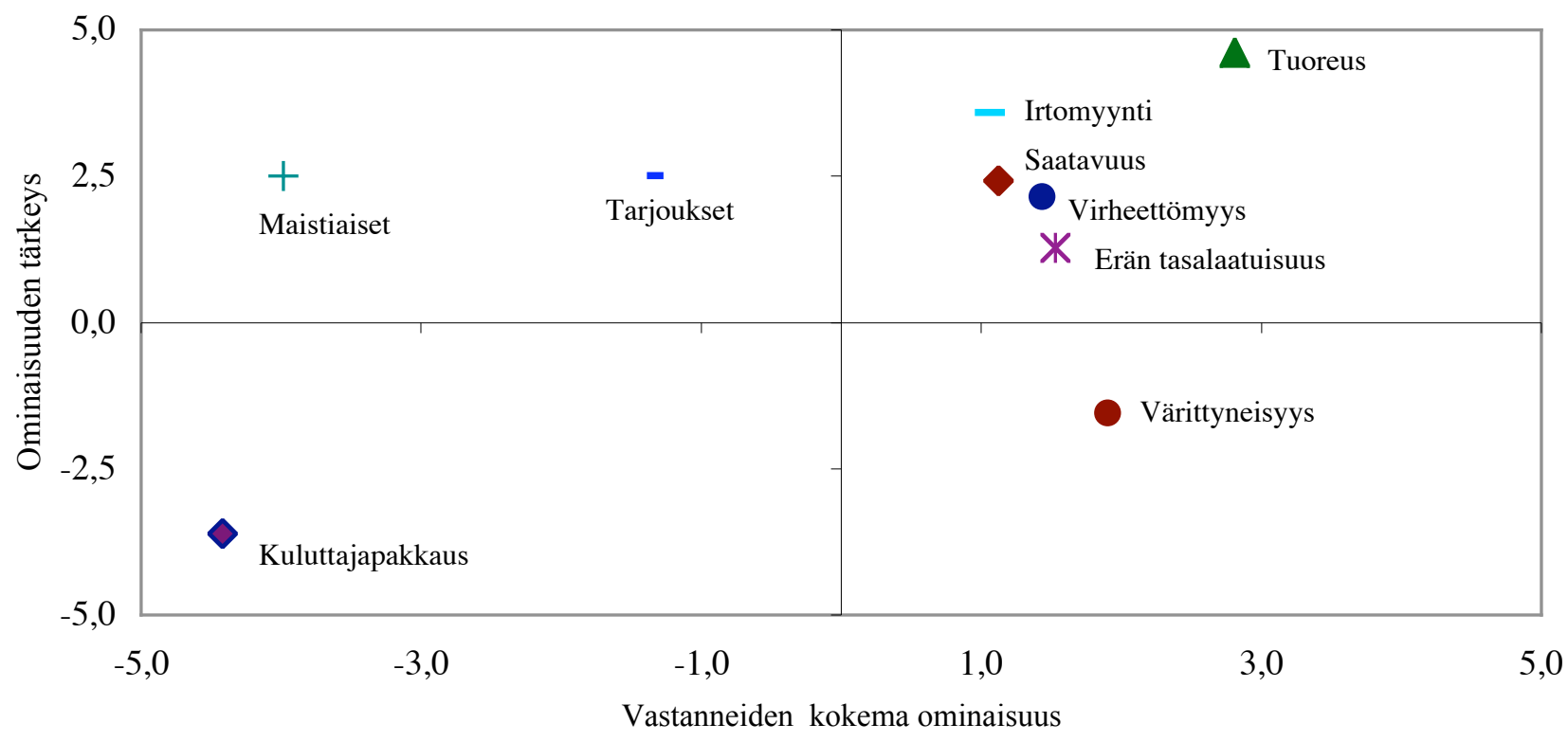

Kuvio 1. Vastanneiden kokema ominaisuus syksyn 2003 kotimaisesta omenatarjonnasta suhteessa ominaisuuden tärkeyteen asteikolla $+5=$ oli erittäin hyvin tarjolla/erittäin tärkeä ominaisuus, $-5=$ ei ollut lainkaan tarjolla/ei lainkaan tärkeä ominaisuus.

Vastanneet pitivät omenoita kohtalaisen tuoreina $(2,8)$, mikä ominaisuus oli erittäin tai äärimmäisen tärkeä $(4,6)$ heille. Saatavuus 1,1 jäi alhaiseksi, kun sen ominaisuuden tärkeyden perusteella olisi tullut olla vähintään 2,6 . Virheettömyys ja omenaerän tasalaatuisuus vastasivat jokseenkin vastaajien odotuksia. Vastaajien näkemyksien mukaan omenat olivat melko hyvin värittyneitä, mutta tällä ominaisuudella ei näyttäisi olevan merkitystä heille $(-1,5)$. Kuluttajapakkauksiin pakattuja omenoita he eivät olleet nähneet, eivätkä he niitä olisi halunneetkaan. Tosin sanallisissa kommenteissa arvosteltiin $10 \mathrm{~kg}: \mathrm{n}$ laatikoita liian suuriksi kerralla ostettavaksi ja toivottiin pienempiä laatikoita, joita jaksaisi kantaa kotiin. Vastanneiden kokema maistiaisten $(-4,0)$ ja tarjousten $(-1,4)$ puute ilmeni selkeästi. Ominaisuuden tärkeys $(2,5)$ arvostettiin saatavuuden kanssa samalle tasolle.

Ennen taustatietoja vastanneilta kysyttiin, miten hyvin he tunsivat tuoreena myytävien omenien laatuluokitusperusteet ja tiesivätkö he, ettei lajittelematonta omenaa saa toimittaa kauppaan. Kolme neljästä ei tuntenut lainkaan omenan laatuluokittelua tai oli vain joskus kuullut tai lukenut siitä. Nykyisin käytössä olevaa omenan ammattiviljelytekniikkaa tai uusia omenalajikkeita tunsi edes jonkin verran $9 \%$ vastanneista. Sitä vastoin pitkään viljelyssä ja kaupassa olleet omenalajikkeet olivat tuttuja puolelle vastanneista. 


\section{Johtopäätökset}

Tutkimustulosten perusteella suomalaiset kuluttajat mieltävät kotimaiset omenat säilöntä- ja lisäaineettomiksi. He pitävät maassamme viljeltyjen omenalajikkeiden mausta ja tuoksusta. Vaikka kotimaisuutta arvostetaan, silti monelle (42\% vastanneista) on yhdentekevää onko omena kotimaista vai ulkomaista.

Kotimaisen omenan suosiminen ostoissa riippuu käytännön toimintamahdollisuuksista ja resursseista. Tällaisia ovat $\mathrm{mm}$. ruoan hinta ja saatavuus, jotka tämän tutkimuksen mukaan nousivat tärkeimmiksi perusteiksi olla ostamatta kotimaista omenaa. Tuontiomenaan verrattuna suomalaisen omenan hinta koettiin korkeaksi. Samoin ihmeteltiin, mistä se johtui. Vastaajien mielestä mielikuvaa kotimaisen omenan korkeasta hinnasta ja/tai markkinoiden kehittymättömyydestä kuvaa hyvin se, ettei omenaa myydä tarjoushintaan, mitä kuluttajat arvostaisivat.

Omenat haluttaisiin ostaa päivittäistavarakaupasta samalla kertaa muiden elintarvikkeiden kanssa. Nykyisin saatavuus koettiin paremmaksi torilla kuin päivittäistavarakaupassa. Omenaa ostetaan usein pienissä erissä. Vain $6 \%$ vastanneista ei ollut ostanut lainkaan ulkomaista omenaa ja kotimaista omenaa noin joka viides (18 \%) vuonna 2003. Tämä johtui osittain siitä, että omenoita kasvatetaan itse ja niitä saadaan myös muilta, mikä oli kolmanneksi yleisin syy olla ostamatta kotimaista omenaa.

Vaikka omenia pidetään terveellisinä, ei sillä ole juurikaan merkitystä omenan ostoihin. Tuoreena ostetut omenat syödään pääasiassa sellaisenaan, eikä niitä juurikaan käytetä ruoanlaitossa. Syynä voi olla se, ettei omenan käyttömahdollisuuksia tunneta riittävästi. Tietoa niin omenan käyttötavoista kuin lajikkeistakin kaivattiin.

Laatu ja maku nähtiin sekä tärkeäksi syyksi ostaa että olla ostamatta kotimaista omenaa. Ristiriitainen tulos voi osittain johtua siitä, että sanoilla saattaa olla erilaisia merkityksiä kuluttajille. Laadun arvioimiseksi vastanneet pitivät tärkeänä, että myytäviä omenia olisi mahdollista maistaa.

Omenan kokoa ei pidetty tärkeänä laatukriteerinä, vaikka se EU sääntöjen mukaan on omenoiden laatuluokitusperuste. Tosin $7 \%$ vastanneista ilmoitti kotimaisen omenan pienen koon olevan syyn jättää omenat ostamatta. Samoin omenan värittyneisyys näyttäisi olevan tämän tutkimuksen mukaan merkityksetön. Kuitenkin Hollannissa ja Englannissa tehdyissä kuluttajapaneelikyselyissä lajikkeen punaisella värillä on todettu olevan merkitystä omenan laatuun vaikuttavana tekijänä (Cliff ym. 1998; Greene 1998).

Koska kysely tehtiin marraskuussa2003, tuloksia on ehditty analysoida vasta kokonaistasolla. Jatkossa aineistoa tutkitaan menestymisvyöhyke- ja kaupunki vs. maaseutujaotteluun perustuen sekä analysoidaan omenan kotitarveviljelyn laajuutta ja merkitystä. Tutkimustuloksiin saadaan syvyyttä, kun niitä edelleen analysoidaan elämäntyyliteoriaa vasten käyttäen faktori- ja klusterianalyysiä.

\section{Kirjallisuus}

Bergström, S. \& Leppänen, A. 1999. Yrityksen asiakasmarkkinointi. 4. uud. painos. Edita Oy. Helsinki. 362 s. Cliff, M., King, M. \& MacDonald, R. 1998. Sensory characteristics of four strains of 'Fuji' apples. Fruit Variation Journal. 54: 205-210.

Greene, D. 1998. Promising high quality apples evaluated in New England. Fruit Variation Journal. 52: 190-199.

Grunert, K.G., Brunso, K. \& Bisp, S. 1993. Food-related life style: Development of a cross culturally valid instrument for market surveillance. MAPP working paper. 12: 38.

Krannila, A. \& Paalo, A. 1996. Omenapuu. Maatiainen ry. RakennusalanKustantajatRAK. Gummerus Kirjapaino Oy. Helsinki. $94 \mathrm{~s}$.

Lotti, L. 1996. Markkinointitutkimuksen käsikirja. 3. uud. painos. WSOY:n graafiset laitokset. Porvoo. 265 s. Shepherd, R. \& Sparks, P. 1994. Modelling food choice. Teoksessa: MacFie, H.J.H. ja Thomson, D.M.H. (toim.) Measurement of Food Preferences. Blackie Academic \& Professional. London. s. 202-226.

Tillgrén, S. 2002. Mansikan kuluttajien elämäntyylit pääkaupunkiseudulla. Helsingin yliopisto Maatalousmetsätieteellinen tiedekunta. Taloustieteenlaitos. Helsinki. $117 \mathrm{~s}$. 